\title{
CONTRIBUTING FACTORS TO THE VIOLENT BEHAVIOUR IN VARIOUS SOCIAL CONTEXTS
}

\author{
Mariana STANCIU1 \\ Adina MIHĂILESCU2 \\ Livia ŞTEFĂNESCU ${ }^{3}$ \\ DOI: https://doi.org/10.35782/JCPP.2021.4.02
}

\begin{abstract}
In the first part of this article, we present an analysis of the concept of violent behaviour in various social contexts and in the international sociological literature. In the second part, we approach the concrete factors that favor the manifestation of violence in different conjunctures, in Romania and in the world, as there is the problem of consequences determined by the widespread mentality of acceptance / tolerance of the domination of masculinity in social life, but also the problem of excessive popularization of the violence subculture through the media. The perspective of the increased incidence of social violence is also addressed as an effect of the chronic phenomenon of poverty in certain types of families. The data and information used come from international and national sources as WHO, UN or NIS Bucharest, but also from the scientific results of the authors who belong to the Research Institute for Quality of Life, Romanian Academy, Bucharest.
\end{abstract}

Keywords: interpersonal relationships, gender-based violence, subconscious aggression, "bullying", persistent poverty.

\section{The concept of violent bebavior in various social contexts}

The definition of the concept of violent behavior can be generic - as in the definition given by the WHO (2002) - or it can refer to some concrete social contexts as in car traffick, in domestic life, in schools etc.. The World Health Organization defines violence in terms of intentional use of force or power, effectively or as a threat, against

1 Senior Researcher, The Research Institute for Quality of Life, Romanian Academy, e-mail: mariana3stanciu@gmail.com

2 Senior Researcher, The Research Institute for Quality of Life, Romanian Academy, e-mail: adina.mihailescu@yahoo.com

3 Senior Researcher, The Research Institute for Quality of Life, Romanian Academy, e-mail: livia.stefanescu@gmail.com 
oneself or another person, against a group or a community, with a high probability of hurting, killing, or affecting psychologically the concerned person/ persons (World Health Organization, 2001). The WHO also considers that violence against women is one of the most important health problems in the world, being also the most important violation of human rights. Currently, one of three women are victims of domestic violence (more than 700 million people) (WHO, 2021). Violent behavior generates extremely serious social problems, affecting all age groups and social status.

High frequencies of violent behavior occur in areas such as:

- married life, as a result of the dominant tendencies on the part of one or both partners, based on mistrust and / or affected by incompatibility in terms of partners' personality;

- family life, as a result of conflicts between spouses, between parents and children or between siblings;

- life at work, when mobbing and/or bullying apear, as an effect of various poles of competitive power, which can cause economic and social harm;

- school life, as a result of conflicts between some teachers and students or manifestations of bullying in the relationship between students;

- car traffic relations, as a result of conflicts that arise between traffic participants;

- relations in the public space in some political or administrative institutions, or where long waiting times are required for the public, in accessing services etc.

- in the neighboring space, especially when some noisy manifestations or some misunderstandings between neighbors apear etc.

In 2018, the World Health Organization initiated an analysis of data from 2000-2018 for 161 countries and territories in collaboration with the UN Inter-Agency Working Group on Violence Against Women. The conclusion of this report was that worldwide one of three women are victims of gender-based violence. COVID-19 pandemic lockdowns have increased the cases of male partner abuse, while access to social services or other forms of support has been limited (WHO, 2021).

UNICEF set the alarm against domestic violence during the pandemic. In a statement posted on the organization's website, UNICEF highlights the increased risk for women and children living with an aggressive man. If before the pandemic, the woman and the children left the aggressor's house and lived in a shelter or with friends, now the victim is forced to stay in the same house with the male aggressor, a situation that predisposes to domestic violence (UNICEF, 2020).

Romanian legislation defines domestic violence by Law 217/2003 (republished), in Art. 3 , by any action or threat of physical, sexual, psychological, economic, social, spiritual or cyber violence that occurs in the family between domestic spouses or ex-spouses, as well as between current or former partners, regardless of whether the aggressor lives or has lived with the victim. " (Romanian Police, 2021). According to Law 217/2003, Art. 4, domestic violence can have the following forms: 
20 | Contributing factors to the violent behaviour in various social contexts

a) verbal violence - addressing through offensive, brutal language;

b) psychological violence - imposition of personal will or control, provocation of states of tension and mental suffering, through any way, blackmail, demonstrative violence against objects and animals, ostentatious display of weapons, neglect, coercion, pursuit without right, supervision of the home and others;

c) physical violence - injury in any form and of any intensity, through various actions, submission to exhausting physical exertion or to activities with a high degree of risk for life, health and bodily integrity;

d) sexual violence - sexual aggression, imposition of degrading acts, harassment, intimidation, manipulation, brutality, marital rape;

e) economic violence - prohibition of professional activity, deprivation of economic means, including primary, such as food, medicine, basic necessities;

f) social violence - imposing isolation of family, community and friends, prohibiting attendance at school or workplace, prohibition / limitation of professional achievement, imposing isolation, including in the common home, deprivation of access to living space, dispossession of identity documents, intentional deprivation of access to information, other actions with similar effect;

g) spiritual violence - diminishing the satisfaction of moral-spiritual needs by prohibiting, limiting, ridiculing, penalizing the aspirations of family members, access to cultural, ethnic, linguistic or religious values, prohibiting the right to speak in the mother tongue and to teach children to speak in their mother tongue, other actions with similar effect or repercussions.

h) cyber violence - online harassment, online messages inciting hatred based on gender, online harassment, online threats, non-consensual publication of information and intimate graphic content and others.

Under no circumstances may custom, culture, religion, tradition or honor be considered justifiable for any act of violence defined by law. (Romanian Police, 2021).

Over the last three decades, social research has been paying less attention to other forms of violence, such as car traffick violence, violence perpetrated by children in schools and outside schools, public policy violence or various forms of violence in the workplace.

Gender-based violence is defined on the basis of existing statistical data, according to which acts of violence initiated by men against women are much more frequent than those initiated by women against men. As a result, gender-based violence is defined as "any act of violence initiated by a man against a woman, which results in or is likely to result in physical, sexual, psychological trauma or suffering, threats of such acts, coercion or arbitrary deprivation of freedom, acts that can be committed against women in public or private life $" 1$.

Domestic violence can have various expressions, more or less visible outside the home, such as physical, psychological, sexual, economic or social violence. Domestic violence

${ }^{1}$ Declaration on the Elimination of Violence against Women, UN General Assembly, December 1993 
can be defined as "any form of aggression, abuse, or intimidation directed at a family member, blood relative, or other family members" (Correctional Service Canada, 1988).

Another massive is the violence in road traffic. It can take two main expressions: the aggressive style that results in accidents in road traffic; it involves the execution of maneuvers that endanger the lives of drivers but also of other road users, by obstructing the legitimate intentions of traffic partners, non-compliance with the appropriate distance between vehicles, rapid, unpredictable or excessive change of lanes etc., or adopting an attitude called "road rage" consisting of displaying obscene gestures, using insulting language or manifesting episodes of physical violence against other road users. The factors that can trigger such behaviors are quite numerous and involve the manifestation of latent tendencies of (sub) conscious aggression existing in the emotional structures of many people, facilitated by their lack of civic education, especially against the inconvenience of traffic conditions (blockages traffic delays, prolonged traffic delays, congestion on traffic lanes, etc.).

According to a study conducted by the $A A A$ Foundation for Traffic Safety, in the United States, there are, on average, more than 1,200 reported incidents annually, caused by aggressive driving, and their number is constantly growing. Problematic traffic behavior of drivers generates about $94 \%$ of the total number of accidents, of which up to $33 \%$ are classified as road rage. In the US, road rage incidents identified by the authorities have increased by $500 \%$ over 10 years (2006-2015) and continue to increase (data of National Highway Traffic Safety Administration (NHTSA). As a rule, drivers who show a high level of aggression at the wheel are more frequently involved in traffic accidents and receive more speeding fines (Wilson, 2020).

Episodes of aggression in traffic are extremely "contagious", and can cause others to behave aggressively. Some studies show that participating in traffic is one of the top 10 activities that are not recommended to be done to the nerves, because nervous drivers are involved in more accidents, anger generating a "tunnel vision" (nervous drivers look only ahead and risk not seeing a pedestrian or a car if it comes from the side) (time.com).

In Romania, the Road Directorate within the Romanian Police does not distinctly register accidents caused by aggressive driving on public roads. However, there are some clues of aggressive style in traffic, which contributes to shaping an image of the phenomenon. For example, in 2019, at national level, due to excessive speed (irregular or not adapted to road conditions), there were about 1,485 serious road accidents, as a result of which 356 people died and 1,586 were seriously injured (Directorate Road Police within the Romanian Police).

The Romanian legislation applies only in extreme situations (when victims appear) sanctions to drivers who show certain aggressive behaviors, although some steps have been taken to amend the legislation, in the sense of sanctioning such acts. The commission by drivers or by their passengers of aggressive or vulgar acts are sanctioned by art. 102 para. (1) point 22 of the Government Emergency Ordinance no. 195 of 2002, republished, with subsequent amendments and completions.

According to the study "Social attitudes on traffic risk 2018" and the comparative analysis of data collected and processed in the four opinion polls on this topic, conducted 
between 2008 and 2018 by the Romanian Police, it was observed that Romanian drivers - in proportion of $71 \%$ - say that, in the last 6 months, they were in the role of victim rather than aggressor and that they were victims of assaults in traffic in the form of flashes or horns. Such aggressive behavior is more frequently recognized by drivers, followed by threatening or obscene gestures $-47 \%$ or verbal aggression $-40 \%$. The investigation carried out by the Romanian Police, in 2018, was answered by 1,259 active drivers (who drove a vehicle in the last 6 months prior to the investigation) (by telephon investigation). Statistically, men, up to 25 years old and/or drivers of cars with a cylinder capacity of $2,000 \mathrm{~cm} 3$ or more said they adopt aggressive behaviors against other road users (Romanian Police, 2018).

Manifestations of "bullying" / "mobbing" can take place in various social environments: at work, at school, in the neighborhood, in churches, or in / between various institutions, in / between various political groups, or even between nations. The concept of "bullying" comes from the English language, from the word "bully", which means a man who hits other, or emotional or physical abuse; it usually has three main characteristics: it is an intentional process - the aggressor intends to hurt or intimidate someone; the action is progressive and repeated - the same person being subjected to a series of more or less veiled aggressions; it is established on a social context of imbalance of forces - the victim being perceived by the aggressor as vulnerable, or unable to defend himself. Bullying does not always imply the existence of a conflict based on a real problem, but is initiated starting from the desire of the aggressors to assert their power and authority, putting others in an inferior position.

The concept of "mobbing" has many dimensions in common with the concept of "bullying" (see the differences between the two concepts in table 1, p.26, in the study of Tomescu C., Cace S., coord., 2011. Bullying / mobbing phenomena are generated by persons or groups, against whom obtaining concrete evidence is quite difficult (the aggressor being located in a social position, usually superior / at most equal to that of the victim). When they occur at work, such aggressions are particularly problematic and the more harmful socially as the aggressors' behavior is more difficult to prove and stop. This is because, usually, victims are reluctant to disclose such a situation. However, the social scale of the manifestation of such phenomena can be particularly large. For example, the study The 2017 US Workplace Bullying Survey (Namie, 2017) found that almost $60 \%$ of employees in the United States are affected by bullying. In Romania there are few studies on such topics. Existing studies show that the consequences associated with bullying, for example (emotional imbalance, stress, decreased self-esteem, etc.) can be felt both by victims and by potential witnesses, which contributes to generating a social atmosphere dominated by anxiety. Such a state of mind can cause a low performance of work, increased absenteeism, loss of confidence in the management of the institution but also on oneself.

Economic violence is materialized by the illegitimate imposition of control over the economic resources (in financial expression or in natural expression) of a victim, by the dramatic restriction of his autonomy of normal social integration. Economic violence can be seen through its social and economic effects, at different levels: at the individual level, at group or social level - (when different categories of aggressors - for example, certain politicians or political groups exercise illegitimate control (by ignoring the law), 
over the legitimate resources of certain social categories, which are in the position of victims).

Social violence is a concept with a wide spectrum of manifestations and can have the most diverse expressions, causes and consequences. This is often manifested by psychological constraints or by the establishment of an illegitimate control over the life spheres of the victim. In such situations, both the victim and the aggressor may be represented by one or more persons. If the victim is a person, he may be subjected to violence by isolating himself from his family or friends, by illegitimately monitoring his activities, by interrupting or limiting his contacts and social relations, by restricting his access to information or assistance. A collective aggressor can have the most diverse structures and social insertions, starting from simple groups of people, coalitioned around common goals or close ideals, determined to dominate by violent means another or other groups, and can reach up to when forming mafia clans or political groups, determined to achieve some goals through methods that ignore the ethical principles of coexistence in society.

\section{Domestic violence in international literature}

Renzetti and Larkin (2009) analyze the interaction between economic factors, social class and domestic violence. Studies that have investigated domestic violence in all social classes show an inverse relationship between a woman's financial status and the risk of becoming a victim. Specifically, the higher a person's social class, the lower the risk of becoming a victim of domestic violence. This is observed in several studies which assumes that the relationship is statistically significant. It is also possible that rich women can hide better when they happen to be victims of domestic violence. For example, in the case of an assault, they can stay in a hotel and not in a shelter for abused women.

In Renzetti and Larkin (2009) employment is used as a social indicator for women victims of domestic violence. According to these authors, women victims who want to work have more problems at work, as a result of domestic violence. The victims report several physical and psychological problems as a result of the violence suffered, problems which affect their quality of employment and the quality of their work. Aggressive partners may intervene in the sense that the partner cannot find a job or go to work. The fact that a woman is employed does not "protect" her from being a victim of domestic violence.

A better predictor of male aggression is the employment status of the partner, as well as the cultural norms of male domination to the detriment of women. An important factor for stopping domestic violence is represented by social networks (family and friends of the victim), who can help the woman with temporary accommodation.

Kaukinen and Powers (2014) make a comparison between victims of domestic violence in the United States and Canada, in terms of a woman's financial contribution to family wellbeing and the risk of becoming a victim of domestic violence. American women seem to have twice as much social risk as Canadians. Income reduces the risk of violence for 
both Americans and Canadians, while women's education provides "protection" in the United States, but not in Canada.

Matjasko et al. (2018) conducted research in North America on domestic violence and reveals the multitude of factors that generate domestic violence: economic factors (low income), social and psychological factors (isolation, inclination to aggression, patriarchal gender roles that require for the husband to be the head of the family and the woman to submit to the husband, low-income people and minorities (black Americans) with sufficient incomes).

\section{Factors that favor the manifestation of violence in different situations}

Violence is a learned social behavior. Most of the aggressors were once victims. And for many of the victims there is a high probability that in the future they will become aggressors. Among the social institutions that teach the lesson of violence, quite often are: family, school, road traffic, the neighborhood or community, some political institutions and military institutions, the military and geo-strategical blocks. The situations in which the manifestation of violent behaviors is found can be extremely different - both as a field of life and as social roles of the subjects involved. What such situations have in common, is the failure of civilized social communication strategies, presumed by engaging people in sustaining peaceful social relations. This can happen on the background of the action of some favoring factors which can be quite numerous, some being active at the level of general opinion, but others act partially or exclusively at the level of the subconscious. Among these factors we mention the most common:

\section{A mentality problem: tolerance / tacit acceptance of the domination of masculinity in social life}

In every society, be it traditional or modern, power is usually expressed through different social roles that belong to, and overlap to a large extent, with the sphere of masculinity. Power as a traditional and main attribute of masculinity (exceptions strengthen the rule), is that which unmistakably delimits a series of attributes belonging to various roles, in the sphere of family life or of other social groups, in the world of politicians, in the environment of public life authorities, in the world of driving in traffic etc. Here are some roles that speak for themselves about their implicit relationship to the concept of domination and power:

- the roles of husband / father / grandfather / first son etc. as well as the role of officer / commander, political leader, head of organization or of a business etc., they fully benefit from the social mentality regarding "male superiority" and are, as a rule, responsible factors - simple or composed with other elements of role and/ or social status - for the manifestation of the phenomenon of violence in social life. For example, the acceptance of the dominant role of the man in the family, manifested, in the family of origin of the woman / wife, in case of a divorce; the 
woman is usually considered responsible for maintaining the balance and stability of a family, precisely through an obedient attitude towards her husband's alleged prerogatives; if, for example, in the event of a divorce, the woman retires, in a first stage, at her family of origin, but there, she may not face an attitude of discouraging her separation; such an attitude is usually attributed to the intention to save a marriage that shows signs of dysfunction; permissiveness of this type can even reach the expression of tolerance towards physical and psychological violence in the couple;

- the role of the head of an organization or a political party president in the implementation of collective decisions; his abusive or more or less discretionary manifestation can be seen, for example, clearly, from the way in which certain mayors distribute community resources to certain economic agents or beneficiaries.

\section{Excessive popularization through the media of the subculture of violence}

In today's society, mass media institutions are a so-called fourth power in the state with a strong position in the sphere of social influence. Both from the media and the internet, positive/ undesirable influences from the perspective of general interest may be induced. Journalistic ethics is, in fact, two-dimensional. On the one hand, the threats that may arise to journalists, and on the other hand, the threats that journalism can produce in society. Threats to journalists usually come from representatives of toxic, hidden societal interests, which are attacked by the journalistic act. Against these, state institutions, through legal regulations, and through appropriate institutions, should protect journalism and the media system.

The elites of the community of media and of the academic institutions issue ethicaldeontological prescriptions, meant to protect the public in relation to the lack of ethics of some jurnalistic practices, of some media system, or of some internet operators. However, the effectiveness of the measures against such threats is quite low, as there is an asymmetry between attempts to regulate media activities and the social risks regarding press freedom. Often, before being threatened, journalists, for example, are themselves considered a threat to the persons' right to their own image.

On the other hand, as some of the states issue sometimes excessive or inefficient policies, the self-imposed ethics by the media community is rather superficial, lacking of depth and axiological vision. The reasons why the state reacts sometimes inefficiently from the perspective of maintaining the rigors of media ethics, are intuitive, as long as state representatives are dominated by their own interests to the detriment of general interest. The attitudes that various mass media generate by commenting on acts of verbal or physical violence have a decisive role in strengthening/weakening stereotypes of social behavior that exist latently in society.

Liberalization of media activities, without conducting parallel activities of education, correct information and facilitating the understanding of the principles regarding social coexistence ethics in the public life, can be a factor of generating violence at various 
levels of social behavior. General criminology includes among the causes of the social phenomenon of crime, along with economic factors, socio-cultural factors and other factors, such as impact of the media. Excessive popularization of some acts of violence or conflict situations can have the effect of proliferating new acts of violence in social communities.

Television is widely perceived, especially as a school of delinquency, mainly juvenile delinquency, in that young people tend to mimic the violence they see on the small screen in their daily lives. Also, the correlation between media and terrorism is also analyzed by Isabelle Garcin-Marrou, who observes the probably unintended complicity between the media and terrorism. Such an idea also emerges from the famous statement of the former British Prime Minister Margaret Thatcher, who claimed that "terrorists feed on media advertising". (Garcin-Marrou, 2005).

The subculture of violence has acquired unfathomable social dimensions also due to the composition of its consequences with the subculture of drug use. Along with this, various other deeply antisocial subcultures have proliferated amid the growing failure of the modern family institution and modern education systems, or the establishment of clans involved in the distribution and recruitment of new drug users, prostitution, trafficking, with weapons etc. An important source of negative influence of social behavior derives from the massive marketing of certain computer games with topics that simulate the occurrence of conflict situations.

Today's society fully bears the risks associated with the freedom of information movement because it is non-unitary and very poorly regulated (at the international/national level). Among the respective risks is the facilitation of the coagulation of groups with disguised goals, but in reality antisocial, if not clearly criminal, which they achieve using social media. Beyond its informational and practical utility, the internet as well as television, has also allowed the development of a not negligible criminal side, becoming a real source of inspiration and school for delinquency, or for various categories of terrorists, who communicate through social media. An example in this sense can be the so-called anti-corruption manifestation of August 10, 2018, of the group called \#resist, from Romania, which resulted in the destruction of community property and acts of violence. However, the aims of the event certainly had an agenda looking at the social destabilization and undermining of the political regime in power at the time, following legitimate elections, as a result of foreign interests from abroad.

\section{The risk of poverty and the problem of normal social integration of the individual}

The precarious economic condition of a person does not become a cause of violent social behavior in every case, but yet social practice has shown that, under certain conditions, many groups of people can become violent, based on economic reasons. The economic and social autonomy of a person, at the age of majority, primarily concerns the financial dimension of the cost of living. In modern society, such autonomy acquires a value comparable to that of the absolute living space related to survival, because it conditions 
the normal social integration of the individual. However, such integration is not possible if a person's economic and social situation is affected by poverty.

Dhungel et al. (2017) observe that the risk of domestic violence is correlated with family poverty, but also with the alcoholism and illiteracy of the aggressive husband. Therefore, corroborated with other factors (for example, the existence in the family of addictions to various drugs, the incidence of some major health problems, the longterm persistence of unemployment etc.), poverty is one of the most frequently incriminated factors responsible for the occurrence of domestic violence. The frustrations that appear in case of insufficient access to the purchase of some basic goods or services (food frustrations, frustrations generated by the inability to ensure an adequate temperature in the house during winter or summer etc.) but not only, generate many conflict situations inside the families, the neighborhood or inside the communities. Statistically, the severe financial dependence of the woman on the man, which occurs in many cases of abuse in the couple, can generate over time, situations of intolerance and tension, completed by acts of violence.

The phenomenon of poverty, present in any society, produces consequences in the sphere of human development. People or families who benefit from a low level of wellbeing, gravitating around the poverty line, usually face three major problems:

- diminishing the functional autonomy in the society and the inability to overcome the respective situation, moment in which the state should intervene through public policies;

- the inability to cover the expenses imposed by the value of the minimum decent consumption basket, accepted in the respective society, leads to the appearance of some social and even biological risks, if the situation persists for a long time (years); thus, there is exclusion and an increased risk of social alienation;

- inability or reduced capacity to access and capitalize on economic aid opportunities offered by the social protection system. Social protection programs must take into account not only the population below the poverty line but also the population located in the area of economic precariousness, or socio-economic risk.

In absolute poverty the individual does not have access to the satisfaction of basic needs (the individual cannot eat, cannot wear clean clothes, does not have access to housing etc.). Such a situation leads the individual and his family to a quality of life that may go beyond the desirability of life.

Relative poverty is assessed in relation to the evolution of the society in which the phenomenon is assessed. There is also a category of people called the new poor. These are people who previously could meet their basic needs, but who, due to new social circumstances, become deprived of access to a socially acceptable way of life. The reasons why a person and his family may fall into poverty are: long-term unemployment, a serious illness, over-indebtedness, the situation of widowness or divorce (Brémond, Geledan, 1995). All these circumstances should lead the authorities of social protection institutions to the people, to help them materially, financially or through any other social assistance services. 
According to the data provided by the NIS regarding the socio-occupational categories of Romania, the most affected by poverty, in the last thirty years in the Romanian society were: in the 1 st decile of income, the families of the unemployed and those of farmers, in deciles 2, 3, 4, the families of the unemployed, farmers and pensioners, who live on a single average social insurance pension or on one or two guaranteed minimum pensions (the minimum social pension has been granted since 2010), but also families of employees living on the minimum wage in the economy.

The coverage of the minimum consumption needs in the urban environment, for the family of two active adults with two dependent children, who had a minimum net salary and two child allowances, during October 1989-2018, shows that such a family, in the last 30 years of recent history, never have been able to cover their needs at the subsistence level, and even less at the level of the decent minimum consumption basket (Chart 1).

\section{Chart 1. Coverage (\%) of the minimum decent basket and subsistence basket of consumption, for the urban family of two active adults with two children, baving a minimum net salary and two children allowances}

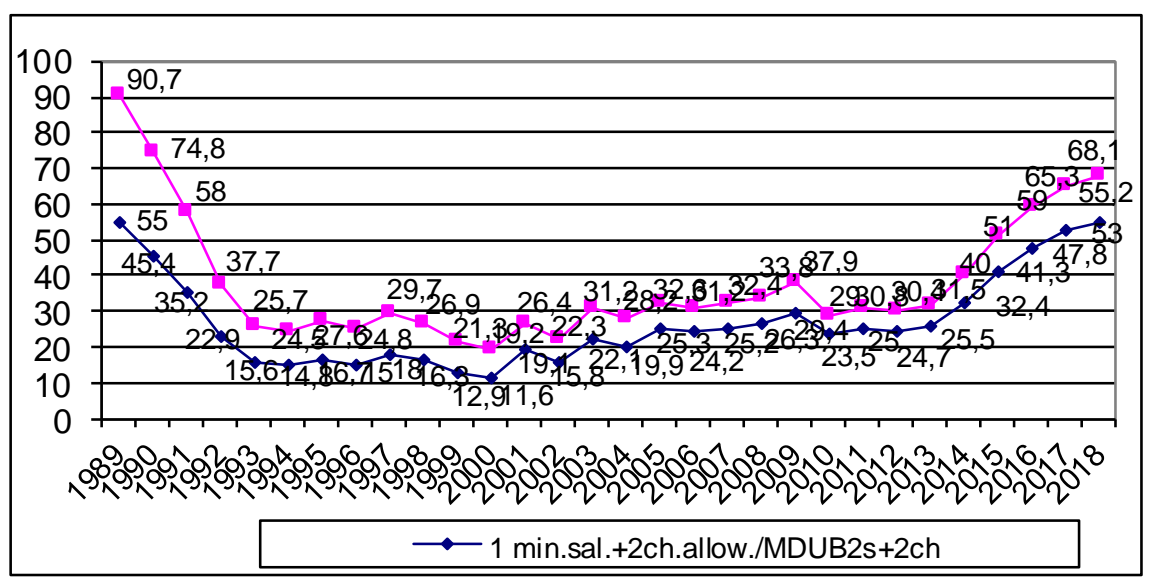

Source: the values of the minimum consumption baskets of the Romanian population were calculated based on the normative method, by A. Mihăilescu; net minimum wage values: website of the Ministry of Labor, Family, Social Protection and the Elderly.

Note: $M D U B=$ the value of the minimum decent urban basket; $M S U B=$ the value of the minimum subsistence urban basket

The economic situation of the same type of family was, perhaps, less dramatic, for the families who had two minimum wages plus two child allowances. They managed to cover, by their incomes, the decent minimum consumption, starting from the year 2018, although it became again impossible with 2020 (Chart 2). 
Chart 2. Coverage (\%) of the minimum decent basket and subsistence basket of consumption, for the urban family of two active adults with two children, baving two minimum net salary and two children allowances

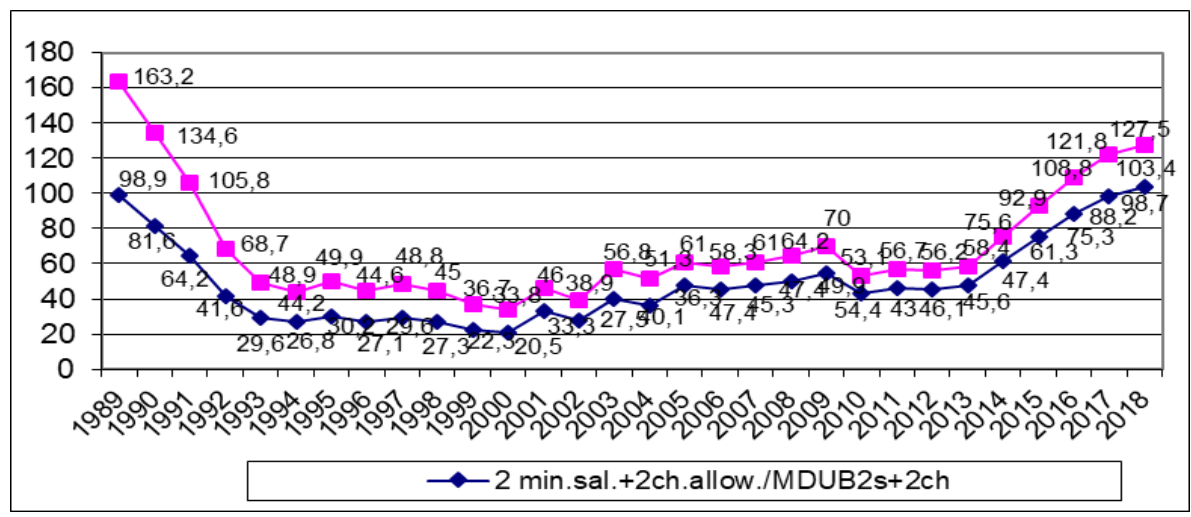

Source: the values of the minimum consumption baskets of the Romanian population were calculated based on the normative method, by A. Mibăilescu; net minimum wage values - website of the Ministry of Labor, Family, Social Protection and the Elderly.

In rural areas, the standard family of 4 people, with two net minimum wages plus two child allowances, had a particularly difficult economic situation at least until 2016 (Chart 3 ), when the coverage of the decent minimum basket of consumption in rural areas for this type of family slightly exceeded the relative value of $100 \%$.

Chart 3. Coverage (\%) of the minimum decent basket and minimum subsistence basket, for the rural family of two active adults with two children, having two minimum net salary and two children's allowances

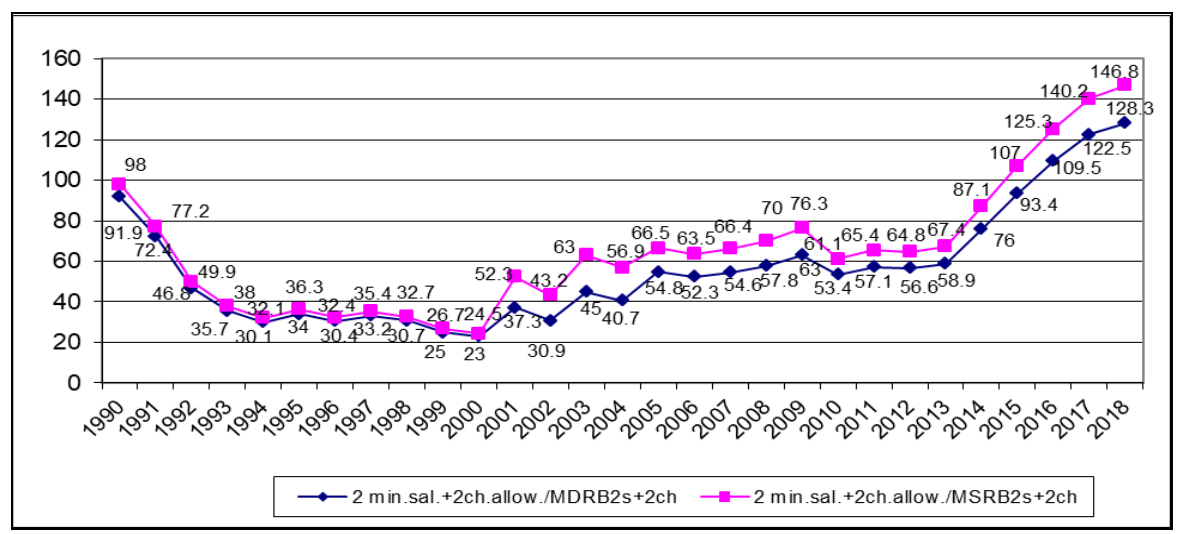

Source: the values of the minimum consumption baskets of the Romanian population were calculated based on the normative method, by $A$. Mihäilescu; net minimum wage values - website of the Ministry of Labor, Family, Social Protection and the Elderly. 
For the family of two active farmers with two dependent children, the value of a decent minimum consumption basket of 3,423 lei was taken into account, calculated according to the normative method, within the Quality of Life Research Institute from Bucharest. The value of such a basket represents $83.7 \%$ of the value of the basket calculated by the National Institute of Statistics. However, a particularly critical situation from an economic perspective exists in the rural families of two people living on a farmer's pension (Chart 4).

Such a family was able to cover its subsistence needs at the highest level of $55 \%$ in 2010, thus continuously enduring a deficit of unimaginable resources even at the average level of quality of life in Romania.

Chart 4. Dynamics of the real average net pension in agriculture compared to the minimum decent basket and the subsistence basket for the rural family of two members $(1989=100 \%)$

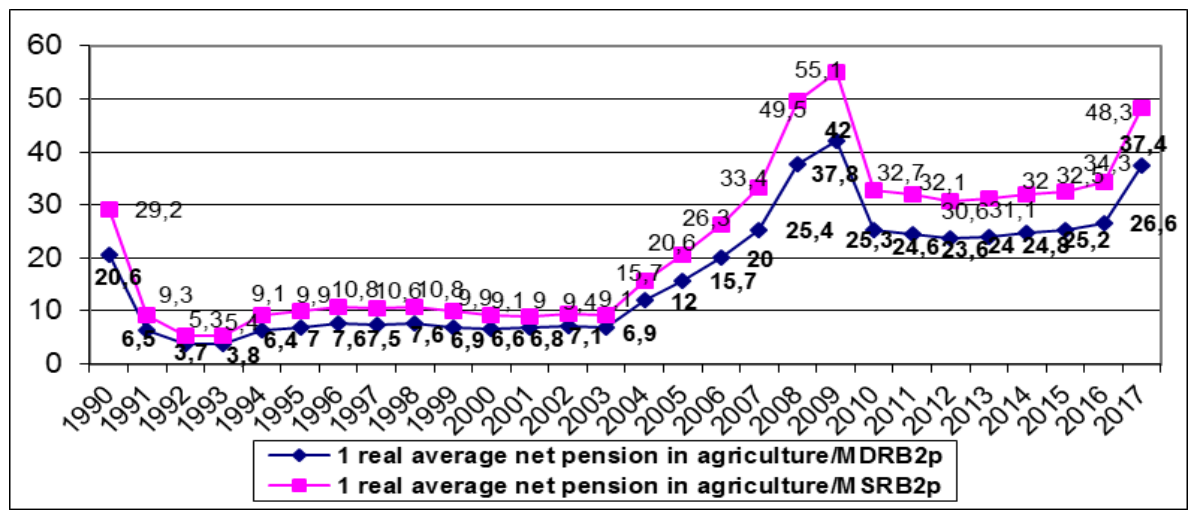

Source: average net social insurance pension in agriculture - NIS, Bucharest, Statistical Yearbook 1990, 1991 ... 2018.). Calculations performed by Adina Mibailescu.

Note: $M D R B=$ the value of the minimum decent rural basket; $M S R B=$ value of the minimum subsistence rural basket.

Such categories of families are presented in this context only to illustrate the depth of poverty in which many families in Romania live. However, these examples are far from exhausting the types of families that accumulate a high potential for violent behavior only starting from the economic and financial argument, without considering other causes.

\section{Conclusions}

Social violence, in all its forms and in all its contexts, is a global problem and is driven by many factors. Domestic violence is determined by psychological, social and economic factors. In the present context, we focused on several categories of violence, given the inevitably small space of this study. Economic factors, such as poverty, unemployment or low incomes, are usually corroborated with the psychological and 
social factors of social violence. Numerous analyzes focus on the field of domestic and gender violence, the dominance of masculinity being a factor of influence that puts more or less its mark on all the manifestations of violent behaviors. As an antidote to this, a very popular concept is gender equality.

Particularly important in this context is the reaction of law enforcement and justice to acts of violence of any kind. In Romania, in this regard, we are extremely deficient. Aggressors often appear in the press who, although they had restraining orders, are not deprived of their liberty.

In Romania, as well as internationally, the pandemic crisis caused many women/ children to suffer as a result of domestic violence, without being able to react and leave the house where the aggressor lived. In Romania, there were 10,000 abused women in 2020 , of whom 72 died as a result of violence. This is only the official statistic, the real number can be much higher (DW, FOCUS, 2020). Although women's education may seem important in preventing domestic violence, many studies show that the effect of male partner education is becoming more relevant. Domestic violence decreases as the level of education of a man in a couple increases. An important aspect is the way in which domestic violence is punished.

In the 10,000 cases of domestic violence reported in Romania, 40\% contained restraining orders, but these were not complied with, by the aggressors. UNICEF Romania warns in a press release of the danger of women and children victims of domestic violence by male aggressors during the coronavirus pandemic, because the victims remained in the same house with the violent person. Expressions widely quoted in Romania such as "the fight is broken from Heaven" or "she certainly did something", are not likely to discourage violence against women and children, who are also the most vulnerable to aggression. Economic factors act in a complex way on domestic violence. They are not the only triggers of aggression, often being accompanied by psychological and social factors.

The Romanian Police published the data for the first seven months of 2021, from which it results that 4882 men and 147 women violent in the family were identified. The number of victims was almost 5,500 people; for more than 4,800 provisional protection orders were issued and about half of them were confirmed by prosecutors. Against the background of the sanitary measures taken in Romania, according to the National Agency for Equal Opportunities between Women and Men, 2.3\% more complaints were registered from women assaulted by their life partners.

A study made by doctors from the University of Medicine and Pharmacy "Carol Davila" and four hospitals in Bucharest, quoted by Newsweek Romania, shows that in the three months of emergency period during the spring of 2021, increased by four times the poly traumas caused by physical aggression resulting from domestic violence. The comparison was made with similar periods in the last three years. The increase of violence during the epidemic has led to a partial change in legislation and the adoption of Law $183 / 2020$ by which aggressors who violate protection orders can be sentenced to between 1 and 5 years in prison.

According to the data from the Bucharest Tribunal, between April 1st and August 20th, 2020, the requests for protection orders doubled compared to the same period of 2019, 
given that the data provided by the ANES Association emphasizes that since the beginning of the year the police have intervened in over 4,000 cases each month, and 1,000 of these cases were at imminent risk. Experts from ANES have concluded that only between 8 and 10 percent of the assaulted victims requested a protection order from the Police or from the judge (DW, FOCUS, 2021).

\section{Acknowledgements}

The study was accomplished inside the Research Institute for Quality of Life, Romanian Academy.

\section{Funding}

The authors received no financial support for the research, authorship, and/or publication of this article.

\section{Declaration of conflicting interests}

The authors declare no conflicting interests.

\section{References}

Brémond J., Geledan A. (1995). Economic and social dictionary, Bucharest: Expert Publishing House, p. $274-276$

Dhungel S., Dhungel P., Dhital S.R. et al. (2017). Is economic dependence on the husband a risk factor for intimate partner violence against female factory workers in Nepal ?. BMC Women's Health 17, 82

Kaukinen, CE, Powers, RA. (2014). The Role of Economic Factors on Women's Risk for Intimate Partner Violence: A Cross-National Comparison of Canada and the United States

Garcin-Marrou I (2005). Media vs. terrorism, Bucharest: Tritonic Publishing House p 81

Kaplan A, Haenlein M (2013). Internet and social movements - social media in the Journal of the Foundation of the National Defense College, no. 1/2013

Matjasko, J L. et al. (2013). The role of economic factors and economic support in preventing and escaping from intimate partner violence, Journal of Policy Analysis and Management. Winter 32 (1): 122-128

Namie G (2017). Workplace Bullying Survey, Workplace Bullying Institute (WBI) U.S.

Rădulescu, M.S. (2001). Sociology of domestic violence, victims, and aggressors in the family Bucureşti: Ed. Lumina Lex

Renzetti, C M., Larkin, V M. (2009). Economic stress and domestic violence, VAWnet: The National Online Resource Center on Violence Against Women, National Resource Center on Domestic Violence (NRCDV), September 2009, accessed online on August 9, 2021

Tomescu C., Cace S. (coord.) (2010). Study on the phenomenon of mobbing and some forms of discrimination at work in Romania, Bucharest: Expert Publishing House

Wilson M. (2020). Why road rage is on the rise and what to do about it, NZ: News hub 
Digi24.ro (2021). $40 \%$ of protection orders are violated. https://www.digi24.ro/ stiri/actualitate/evenimente/40-din-ordinele-de-protectie-sunt-incalcate-infiecare-ora-o-femeie-suna-la-112-pentru-a-si-reclama-partenerii-violenti-1509845, accessed on August 9, 2021

Digi24.ro (2021) The shocking case of the woman beaten in the street, 17.03.2021, https:// www.digi24.ro/stiri / news / health / the-shocking-case-of-women-beaten-inthe-street-illustrates-a-serious-phenomenon-10-000-of-women-beaten-and-72killed-by-partners-in-2020 -1469807, accessed August 9, 2021

DW FOCUS (2021) Home is a dangerous place or about the trap of domestic violence, https: //www.dw. com / ro / acas\% C4\% 83-e-un-loc-periculos-sau-despre-tracanaviolen $\%$ C8\% 9Bei-domestice / a-55718891

INS (1990 ... 2020) Statistical Yearbook of Romania 1990 ... 2020

Partnership Center for Equality (2004). Guide to information and good practices in the field of equal opportunities between women and men, p. 55

Official Monitor no. 948, October 15, 2020, Law no. 217 of May 22, 2003 (republished) for preventing and combating domestic violence, http://legislatie.just.ro/Public/DetaliiDocument/ 44014

Ministry of Labor and Social Solidarity. Press release http://mmuncii.ro/j33/ index.php/ro/comunicare/comunicate-de-presa/3472-2014-08-26-cp-telverde

National Union of External Public Auditors in Romania (2021). Phenomena of bullying / bullying or harassment at work

Romanian Police (2021) Domestic violence, https://www.politiaromana.ro/ ro/prevenire/violenta-domestica/despre-violenta-domestica

T-TIMES (2020). Ten factors that influence the risky behavior of young people bebind the wheel, 29.12.2020, https://t-times.ro/categorii/rutier/10-factori-care-influenteazacomportântul-riscant-al -young-at-the-wheel

UN (1993). Declaration on the Elimination of Violence against Women, adopted by the UN General Assembly in December 1993

UNICEF (2020). During the pandemic, women and children are at risk of being more exposed to domestic violence, December 10, https://www.unicef.org/romania/ro/comunicatede-pres $\%$ C4\% $\% 3 /$ during-the-pandemic-women- $\%$ C $8 \% 99$ i-children-risk $\%$ C4\% 83-s\% C4\% 83-be-more-exposed \% C8\% 99i-violence \% C8\%

United Nations (Department of Public Information) (1995) Fourth World Conference on Women's Issues, Beijing, China, 4-15 September 1995; Beijing Platform for Action and the 1996 Declaration.

World Health Organization (2001). Recommended Ethics and Safety Principles for Research on Acts of Domestic Violence against Women, Priority for Women, WHO / FCH / GWH / 01.1, Geneva, Switzerland

World Health Organization (2002). World Report on Violence and Health, WHO / NHL HV 6625 / edited by Krug, E.G. et al., Geneva, Switzerland

World Health Organization (2021) Violence against women, March 9, https:// www.who.int/news-room/fact-sheets/detail/violence-against-women 